\title{
BMJ Open Difference in factors associated with continuum of care completion rate from pregnancy to postpartum period in rural Nepal: a community-based, cross- sectional study
}

\author{
Ram Chandra Silwal, ${ }^{1}$ Akira Shibanuma (D) , ${ }^{1}$ Amod Kumar Poudyal, ${ }^{2}$ \\ Subaru Ikeda (D) , ${ }^{1}$ Masamine Jimba (D) ${ }^{1}$
}

To cite: Silwal RC,

Shibanuma A, Poudyal AK, et al. Difference in factors associated with continuum of care completion rate from pregnancy to postpartum period in rural Nepal: a community-based, cross-sectional study. BMJ Open 2021;11:e044928. doi:10.1136/ bmjopen-2020-044928

- Prepublication history for this paper is available online. To view these files, please visit the journal online (http://dx.doi. org/10.1136/bmjopen-2020044928).

RS, AS and MJ contributed equally.

Received 19 September 2020 Accepted 03 June 2021

A Check for updates

(c) Author(s) (or their employer(s)) 2021. Re-use permitted under CC BY-NC. No commercial re-use. See rights and permissions. Published by BMJ.

${ }^{1}$ Department of Community and Global Health, Graduate School of Medicine, The University of Tokyo, Bunkyo-ku, Tokyo, Japan

${ }^{2}$ Central Department of

Public Health, Institute of

Medicine, Tribhuvan University, Kathmandu, Nepal

Correspondence to Professor Masamine Jimba; mjimba@m.u-tokyo.ac.jp

\section{ABSTRACT}

Objectives This study aimed to investigate the continuum of care $(\mathrm{CoC})$ completion rate in maternal, neonatal and child health and its associated factors among mothers in two ecological regions in Nepal.

Design This was a community-based, cross-sectional study, for which data were collected through face-to-face interviews using a structured questionnaire. Multiple logistic regression analyses were conducted to determine the associated factors.

Setting This was carried out in two rural districts of Nepal, in different regions: one in the hills (Dhading) and another in the flatlands called Terai (Nawalparasi). The data were collected between July and December 2016. Participants Mothers who gave birth within a year before this study were included as participants. In total, there were 1803 participants.

An outcome measure The outcome of this study was measured by the $\mathrm{CoC}$ completion rate when a mother completes four antenatal check-ups, deliver at a health facility and receives postnatal care within 24 hours of delivery.

Results The CoC completion rates were $41 \%$ in Dhading and $28 \%$ in Nawalparasi. In Dhading, shorter travel time to a health facility and higher wealth quintiles were associated with a better $\mathrm{CoC}$ completion rate. In Nawalparasi, the $\mathrm{CoC}$ completion rate was affected by parity and decision-making for pregnancy care.

Conclusions The CoC completion rate was low in both districts in Nepal. However, factors associated with the $\mathrm{CoC}$ completion rate varied by district. Differences in these factors might be reflected by geographical and socioeconomic conditions and the characteristics of household decision making in these districts.

\section{BACKGROUND}

Promoting continuum of care (CoC) from pregnancy to the postpartum period is one of the key approaches to improving maternal and newborn health (MNH). WHO recommends CoC as a cost-effective intervention to improve $\mathrm{MNH}{ }^{1}$ CoC usually refers to the
Strengths and limitations of this study

- In this study, the level of continuum of care was assessed from pregnancy to postpartum periods in two ecological regions of Nepal.

- Women's knowledge and behaviours were measured in these regions as potential factors associated with the continuum of care completion rate.

- Different associated factors were identified with the continuum of care completion rate in two ecological regions.

- Data were collected only from two ecological regions out of three as obtaining sufficient number of data was difficult in the mountain region.

- The mothers might have a chance of recall bias about the services they received since they were asked about them within a period of 1 year after delivery.

continuity of individual care throughout the lifecycle (ie, adolescence, pregnancy, childbirth, postpartum period and childhood) and is explained by two dimensions: space and time. ${ }^{2}$ In practice, the time dimension of CoC emphasise care for both mothers and newborns, from antenatal care (ANC) to postnatal care (PNC). ${ }^{3}$ The space dimension, on the other hand, denotes optimal care-taking at households, communities and health facilities. ${ }^{4-7}$

Several mothers and newborns do not receive $\mathrm{CoC}$ owing to demand-side and supply-side barriers. Major demand-side barriers against access to MNH health services comprised the following factors: lack of awareness about pregnancy and postpartum care, long distance to health facilities, geographical difficulties, inadequate transport facilities, financial constraints and lack of empowerment of women, particularly in 
decision making regarding moving out from home..$^{8-11}$ Major supply-side barriers include inaccessibility and absenteeism of health workers and unavailability of services. ${ }^{12} 13$ These elements from both sides serve to prevent women from receiving essential services. Nepal Demographic Health Survey (NDHS) (2016) showed that $69 \%$ of the women received four ANC, $58 \%$ of them delivered at the health facility and $57 \%$ received $\mathrm{PNC}$ within 2 days of delivery. ${ }^{14}$

Ensuring the provision of $\mathrm{CoC}$ to mothers and newborns is vital for improving MNH indicators in Nepal. Therefore, since 1997, the Government of Nepal (GoN) has prioritised improving $\mathrm{CoC}$ in $\mathrm{MNH}$, making a policy to expand birthing centres down to the Village Development Committee (VDC) level, and also stressing on improving MNH services across the country. ${ }^{15}$ If women receive ANC services continuously, they tend to follow the recommended actions and are more likely to give birth at health facilities, subsequently receiving proper care for their child. Moreover, women are more likely to seek PNC if they underwent full ANC and delivery care at a health facility. ${ }^{1}$ However, in Nepal, many women fail to receive PNC even after completing four ANC. ${ }^{14}$

Multiple factors are known to be associated with CoC completion rate in Nepal. These factors include distance to health facilities, ethnicity, access to radio and television, spousal communication, frequency of ANC, knowledge on ANC and PNC, wealth quintile, education, parity and decision-makers for ANC and delivery. ${ }^{16-18}$ These factors, however, have not been identified considering regional differences. Nepal consists of nearly 60 ethnic groups, and people live in three ecological regions; mountain $(4877-8848 \mathrm{~m})$, hill $(610-4876 \mathrm{~m})$ and flatland called Terai $(<610 \mathrm{~m}) .{ }^{19}{ }^{20}$ The type of the factors for CoC completion rate may vary among these ecological regions.

For taking a tailor-made public health approach to improve CoC completion rate, investigating the regionspecific factors are crucial. In this study, the CoC completion rate was first analysed among mothers from two ecological regions in Nepal. Then, associated factors with the CoC completion rate were investigated in each region.

\section{METHODS}

\section{Study design and setting}

This community-based, cross-sectional study took place in two ecological regions in Nepal.

Nepal is divided into 75 districts, among which 16 lie in the mountains, 39 in the hills, and 20 in the Terai. The hills form the largest part of Nepal (ie, $68 \%$ of the total land). However, the largest share of the population lives in the Terai (ie, $44 \%$ ), despite it only covering $17 \%$ of the country's total landmass. Each ecological region has unique characteristics regarding climate, geography, infrastructure, culture and access to health facilities. The districts segregate into smaller administrative units, municipalities and VDCs, which further branch off into wards, representing the smallest administrative unit.

In this study, two districts were purposively selected: Dhading, a hill district, and Nawalparasi, a Terai district. The mountainous region was not targeted, as obtaining a sufficient number of mothers was difficult. Dhading is the adjoining district of Kathmandu, the Capital of Nepal, which is also the only district where Comprehensive Obstetric Care is available. Nawalparasi, on the other hand, shares a border with India and lies in a Terai region. The majority of the people belong to Terai-origin ethnic groups, such as the Madheshi. Dhading district has a total population of 336067 (178 233 women), while Nawalparasi has a total population of 643508 (339 833 women). ${ }^{21} 22$ This study was conducted in a western part of Nawalparasi with a total population of 343886 (177 305 women). The chosen districts were comparable based on the availability of health facilities and the target population according to the Health Management Information System. At least one health facility was available in each VDC. Both districts had a referral hospital for managing pregnancy-related complications. To balance population sizes while covering different geographical areas, 37 VDCs from the West part of Nawalparasi were included in this study. District headquarters and municipalities, however, were excluded from both districts.

The 2015 earthquakes heavily affected Dhading, thus the research team chose less-affected VDCs for this study. In the 49 VDCs and 1 municipality under Dhading, the earthquake caused 733 deaths; as such, the 12 selected VDCs were defined as less-affected areas. ${ }^{22}$ This study was conducted one and a half years after the disaster.

About 60 diverse ethnic groups in Nepal are delineated using language, ethnic identity or the delineated using language, ethnic identity or the caste system. ${ }^{23}$ Ethnicities are also categorised by common culture or the custom of marrying only within the limits of a local community, clan or tribe. In this study, ethnic groups were classified into seven categories, as defined by the Central Bureau of Statistics, ${ }^{24} 25$ namely: (1) Brahmin/Chhetri, (2) Terai/ Madhesi castes, (3) Dalits, (4) Newar, (5) Janjati, (6) Muslims and (7) others.

\section{Patient and public involvement}

The details of the study plan were shared with the district level health administrators. They provided the list of local level healthcare providers. The list of eligible mothers was then prepared together with local level healthcare providers such as Auxiliary Nurse Midwives (ANMs) and Female Community Health Volunteers (FCHVs). Prior to study, seven potential participants reviewed the study instruments and provided their comments. Detailed information of the study was provided to household heads and obtained their permission before recruiting the study participants. After learning the details of the study, the mothers provided their consent to participate in the study voluntarily and provided information. The main results of the study were shared with in-charge of local health 
posts in both districts, who were willing to address some of the barriers identified in the study. Study findings will be shared with various stakeholders both in study districts and national level.

\section{Participants}

The participants were mothers aged $16-49$ years, who had given birth to a baby within the 12 months preceding this study. Additionally, only married mothers were included; childbearing in unmarried women is not accepted and a rare event in Nepal. The team also excluded mothers who were severely ill at the time of this study.

\section{Sample size}

The sample size was calculated assuming coverage of key MNH services, from pregnancy to delivery and 7 days' postpartum care of $5.8 \%$, with reference to $8 \%$ in a previous study (significance level $=0.05$; power $=0.8$, $\mathrm{df}=2) .{ }^{14}{ }^{26-28}$ The required sample size was 887 for each district; data from 1803 mothers were collected: 903 from Dhading and 900 from Nawalparasi.

\section{Sampling procedure}

Using a two-stage random sampling method, 1803 mothers (ie, 903 from Dhading and 900 from Nawalparasi districts) were selected for an interview. This study used the sampling frame according to the most recent population census of Nepal in 2011. VDC was considered the primary sampling unit and the population of each VDC ranged from 5000 to 15000 individuals. Out of 49 VDCs, data were collected from 12 VDCs in Dhading, and from the 37 VDCs in Nawalparasi, the team obtained data from 11 VDCs. Also, women were randomly selected from each VDC using probability proportional to size.

The household was the secondary sampling unit. To selectit, the research team, consisting of the first author and data enumerators, went to the selected VDCs. Altogether, four data enumerators with experience in conducting interviews were recruited for each district. They were also trained in the process of obtaining informed consent and data collection. They were assigned to consult with local FCHVs and other local key informants to create the list of eligible mothers. FCHVs are the front-line healthcare volunteers in Nepal who update the list of pregnant and post-partum mothers. The list of eligible mothers in each selected household was prepared and confirmed with the FCHVs of the respective ward. The ANMs from the local health post were also consulted to confirm if any mothers were missing.

The data were directly collected from the postpartum mothers. Informed consent was obtained from them before collecting the data. However, mothers-in-law or fathers-in-law were met during the interview as a courtesy. When the data collection team reached the targeted household, the head of family was explained the objectives of visit, who were mostly mothers-in-law or fathersin-law. This was important to build a rapport with them so that they will not be surprised at their daughter-in-law was being interviewed. This is a common practice for fieldwork in Nepal. If more than one eligible mother lived in a household, the team only interviewed the mother of the youngest child. All the mothers were interviewed separately, to safeguard their confidentiality and prevent the influence of any family members. The research team also confirmed the age, date of delivery and the number of children with the mother for her eligibility to partake in this study. If a mother was not present during the first visit, the enumerators made a second visit on the next day, and if she was absent on the second visit as well, the next listed household was selected for an interview.

\section{Measurements}

\section{Dependent variable}

This study used the CoC completion rate as the dependent variable. The CoC completion rate was defined if a mother completes the following cares:

1. At least four ANC check-ups (ANC4+) at 4, 6, 8 and 9 months of pregnancy by the ANM and paramedics or doctors at a health facility, in community outreach clinics or home.

2. Delivery assisted by skilled birth attendants (eg, doctor, nurse/midwife, ANM) at a health facility.

3. PNC for both mother and infant within 24 hours of delivery by health service providers at a health facility.

Different from the standardised WHO guidelines, Nepal changed government the policy in 2007 to change the timing of PNC visits; first in 24 hours of birth (PNC 1 ), second on the third day (PNC 2) and third on seventh day (PNC 3). ${ }^{29} 30$ The first week of births was crucial both to the mothers and newborns in Nepal, which was the reason behind changing the policy. The Nepal Safe Motherhood and Newborn Health Road Map describes the CoC completion rate if a mother completes of all of the above-mentioned visits. ${ }^{30}$ So, only PNC 1 is not the standard definition in Nepal. However, as the rate of PNC 2 and PNC 3 was very low in this study, only PNC 1 was included for analysing the association with CoC completion rate. The above-mentioned indicators were used to construct a binary variable: 1 for mothers who completed CoC, and 2 for mothers who did not complete it.

\section{Independent variables}

This study required the measurement of several independent variables. First, as outlined in the NDHS, the team measured the sociodemographic characteristics: age, education, ethnicity, religion, occupation, travel time to the birthing centre and parity. ${ }^{2631}$

Thereafter, wealth quantiles were measured using a household assets index of 23 variables. The assets index was calculated according to the first component obtained in a principal component analysis, by accounting for house ownership, having a personal mobile phone, water source, availability of electricity at home, toilet type, household assets (including telephones, television set, video decks, refrigerators, cars, motorbikes, bicycles, tractors, cattle), cooking fuel, availability of toilets and drinking 
water. ${ }^{32}$ Data were recorded as 'yes' if the mothers lived in their own home; if the floor of their house was made with parqueting, carpet, tile or cement; if the house used zinc plate, tile, cement, or stone as roofing materials; and if the wall of the house consisted of brick, plywood, cement or block. Additional variables included in the index were the following: having a radio, computer, wall clock, gas geyser or solar panel. The response was also noted as 'yes' if the family or mothers owned any of these items.

Third, the research team also measured other independent variables related to the mothers' most recent pregnancy, delivery and post-natal periods. These were as follows:

1. Participation of mothers in the health mothers group meeting.

2. Knowledge and practice related to four ANC visits.

3. Decision-makers for ANC and delivery.

4. Spousal communication for choosing the place of delivery.

5. Experiencing any complications in pregnancy, delivery and PNC.

6. Planning with their husband to select the place of delivery.

The response was noted as 'yes' if the mothers participated in the meeting; knew about the need of four ANC visitations; sought out four ANC services as prescribed; decided the place of delivery by themselves; shared with their husband; or faced any health problems in pregnancy, delivery and PNC.

In Nepal, many types of mothers' groups exist. Particularly, the health mothers' group is led by FCHVs. Such a group has to be formed in each ward and is supposed to behold meetings every month. During these meetings, women discuss their issues related to maternal, newborn and child health $(\mathrm{MNCH})$.

Planning with their husband to select the place of delivery was considered an independent variable because rural mothers need support from their family members to visit a health facility.

\section{Data collection}

A semistructured questionnaire was used for interviewing the mothers while collecting the data. The questionnaire had been pretested in Nawalparasi.

Data were collected between July and December 2016 by eight experienced data enumerators who received a 3-day training before being assigned to fieldwork. The training focused on sampling households, building rapport, explaining participants, obtaining informed consent and administering the questionnaire. The data enumerators in Nawalparasi were familiar with the local language because many mothers in this district spoke a local language, Bhojpuri. After collection, all of the data were transported to the Kathmandu office of the local non-governmental organization (NGO) Green Tara Nepal.

All of the mothers were provided with an information sheet that contained explanations of the procedures, potential benefits and risks, and expected time for the interview. Furthermore, each mother gave her written informed consent before the interview proceeded; informed consent was read out for illiterate mothers and their thumbprint was taken on the sheet. Participation in this study was voluntary, and confidentiality was assured. Participants could choose to refuse to answer any question or discontinue the interview anytime without giving any reason.

\section{Statistical analysis}

All data were entered into SPSS V.22.0, with missing values being crosschecked to maintain the completeness of the data. Descriptive and inferential statistics were computed. The team performed a descriptive analysis to explore the characteristics of the mothers by stratifying them into multiple categories. Descriptive statistics assisted in evaluating the sociodemographic characteristics of the mothers according to districts. Disaggregated results by districts have been presented in tables and figures.

Multiple logistic regression analyses were conducted to determine the factors associated with the level of CoC completion. ${ }^{26}{ }^{32}$ The OR denotes the odds of mothers with completed CoC, compared with those of the mothers who had not when adjusted for potential confounding variables - mainly age, ethnicity, religion, parity, wealth quintile, distance, knowledge on ANC, experiencing complications in ANC, delivery and PNC. These variables were considered as major contributors to receiving care in MNCH. ${ }^{142032} 33$ The level of statistical significance was indicated by a $\mathrm{p}<0.05$.

\section{RESULTS}

\section{Sociodemographic characteristics of mothers by district}

This study included 903women in Dhading and 900 women in Nawalparasi. Table 1 shows the sociodemographic characteristics of mothers. More than $70 \%$ of the mothers in both Dhading and Nawalparasi districts were from the age group of 20-29 years. The mean age of the mothers was about 24 years in both districts. About 25\% of the mothers in Dhading and $18 \%$ in Nawalparasi were illiterate. Hinduism was the dominant religion in both districts. Furthermore, $61 \%$ of the mothers were from Janjati in Dhading, whereas 59\% of them belonged to Brahmin/Chhetri/Terai-origin ethnic groups in Nawalparasi West. In both districts, more than $50 \%$ of the mothers had two to three children.

Moreover, 23\% of the mothers from Dhading and 55\% from Nawalparasi participated in the health mothers' group meeting. About $83 \%$ of the mothers from Dhading and $56 \%$ from Nawalparasi knew the need to have four ANC check-ups. The record of mothers receiving four ANC check-ups was 52\% in Dhading and around $36 \%$ in Nawalparasi. The odds of the mother deciding the place of ANC by herself were about $80 \%$ in Dhading and about $51 \%$ in Nawalparasi. 
Table 1 Sociodemographic characteristics of mothers by district

\begin{tabular}{|c|c|c|}
\hline \multirow[b]{3}{*}{ Variables } & \multicolumn{2}{|l|}{ Frequency } \\
\hline & Dhading (n=903) & Nawalparasi $(n=900)$ \\
\hline & n (\%) & n (\%) \\
\hline \multicolumn{3}{|l|}{ Age group } \\
\hline Below 20 years & $114(12.6)$ & $80(8.9)$ \\
\hline 20-29 years & $666(73.8)$ & $720(80.0)$ \\
\hline Mean age (SD) years & $24.2(5.1)$ & $24.2(4.2)$ \\
\hline \multicolumn{3}{|l|}{ Education } \\
\hline None & $221(24.5)$ & $162(18.0)$ \\
\hline Primary/lower secondary & $452(50.1)$ & $437(48.6)$ \\
\hline Secondary and above & $230(25.5)$ & $301(33.4)$ \\
\hline Janjati/other caste & $554(61.4)$ & $73(8.1)$ \\
\hline Muslim & $0(0.0)$ & $102(11.3)$ \\
\hline \multicolumn{3}{|l|}{ Religion } \\
\hline Hindu & 790 (87.5) & 786 (87.3) \\
\hline Other & $113(12.5)$ & $114(12.7)$ \\
\hline \multicolumn{3}{|l|}{ Travel time to birthing centre } \\
\hline Less than $15 \mathrm{~min}$ & $98(10.9)$ & $148(16.4)$ \\
\hline $15-60 \min$ & $481(53.3)$ & 709 (78.8) \\
\hline \multicolumn{3}{|l|}{ Wealth quintiles } \\
\hline Highest & $336(37.2)$ & $23(2.6)$ \\
\hline \multicolumn{3}{|l|}{ Parity } \\
\hline One & 378 (41.9) & 278 (30.9) \\
\hline Two & $300(33.2)$ & $312(34.7)$ \\
\hline Three or more & $225(24.9)$ & $310(34.4)$ \\
\hline \multicolumn{3}{|c|}{ Mothers participated in health mother's group meeting } \\
\hline Yes & $208(23.0)$ & $498(55.3)$ \\
\hline No & $695(77.0)$ & $402(44.7)$ \\
\hline \multicolumn{3}{|l|}{ Knowledge on 4 ANC check-ups } \\
\hline Yes & $747(82.7)$ & $501(55.7)$ \\
\hline No & $156(17.3)$ & $399(44.3)$ \\
\hline \multicolumn{3}{|l|}{ Completed 4 ANC check-ups } \\
\hline Yes & $466(51.6)$ & $320(35.6)$ \\
\hline No & $437(48.4)$ & $580(64.4)$ \\
\hline \multicolumn{3}{|l|}{ Decision makers for ANC } \\
\hline Self & $721(79.8)$ & $460(51.1)$ \\
\hline MIL & $129(14.3)$ & $116(12.9)$ \\
\hline
\end{tabular}


Table 1 Continued

\begin{tabular}{|c|c|c|}
\hline \multirow[b]{3}{*}{ Variables } & \multicolumn{2}{|l|}{ Frequency } \\
\hline & Dhading ( $\mathrm{n}=903)$ & Nawalparasi $(n=900)$ \\
\hline & n (\%) & n (\%) \\
\hline Husband & $8(0.9)$ & $131(14.6)$ \\
\hline Other family members & $23(2.5)$ & $154(17.1)$ \\
\hline Don't know & $22(2.4)$ & $39(4.3)$ \\
\hline \multicolumn{3}{|c|}{ Planning with husband for place of delivery } \\
\hline Yes & $777(86.0)$ & $713(79.2)$ \\
\hline No & $126(14.0)$ & $187(20.8)$ \\
\hline \multicolumn{3}{|l|}{ Decision-makers for delivery } \\
\hline Self & $681(75.4)$ & $247(27.4)$ \\
\hline Others (MIL, husband, FIL) & $222(24.6)$ & $653(72.6)$ \\
\hline \multicolumn{3}{|c|}{ Experienced any complications in pregnancy } \\
\hline Yes & $235(26.0)$ & $552(61.3)$ \\
\hline No & $668(74.0)$ & $348(38.7)$ \\
\hline \multicolumn{3}{|c|}{ Experienced any complications during delivery } \\
\hline Yes & $101(11.2)$ & $224(24.9)$ \\
\hline No & $802(88.8)$ & $676(75.1)$ \\
\hline \multicolumn{3}{|c|}{ Experienced any complications in PNC } \\
\hline Yes & $136(15.1)$ & $417(46.3)$ \\
\hline No & 767 (84.9) & $483(53.7)$ \\
\hline
\end{tabular}

ANC, antenatal care; FIL, father-in-law; MIL, mother-in-law; PNC, postnatal care.

During the pregnancy period, about $80 \%$ of the mothers from both districts discussed the place of delivery with their husbands. In Dhading, $75 \%$ of the mothers decided the place of delivery independently, whereas only $27 \%$ in Nawalparasi reported the same. Further, $26 \%$ of the mothers from Dhading experienced complications in pregnancy, whereas $61 \%$ went through this ordeal in Nawalparasi. Likewise, $11 \%$ of the mothers from Dhading experienced problems at the time of delivery, whereas in Nawalparasi, such incidences were reported by $25 \%$ of the mothers. Nearly $15 \%$ and $46 \%$ of the mothers from Dhading and Nawalparasi, respectively, experienced problems in the postpartum period.

\section{Coverage of MNH services}

Figure 1 presents the CoC completion rate by the district. In sum, $52 \%$ of the mothers in Dhading completed four ANC check-ups, whereas $36 \%$ did so in Nawalparasi. About $70 \%$ of the mothers in both districts gave birth in a health institution. The first PNC showed records similar to the statistics for institutional delivery in both districts. The CoC completion rate was $41 \%$ in Dhading and $28 \%$ in Nawalparasi. This outcome validates a significant difference between the districts (adjusted OR (aOR): $1.75,95 \%$ CI: 1.44 to 2.13$)$. Still, the reception of additional PNC on the third and the seventh day after birth was reported for only $6 \%$ of women in Dhading and 3\% in Nawalparasi and varied considerably by district (aOR: $1.95,95 \%$ CI: 1.23 to 3.09$)$.

\section{Factors associated with $\mathrm{CoC}$ completion rate}

The multivariable analysis verified that the following factors were significantly different in at least one district: travel time to a health facility, wealth quintiles, parity, decision-makers for ANC, planning with husband

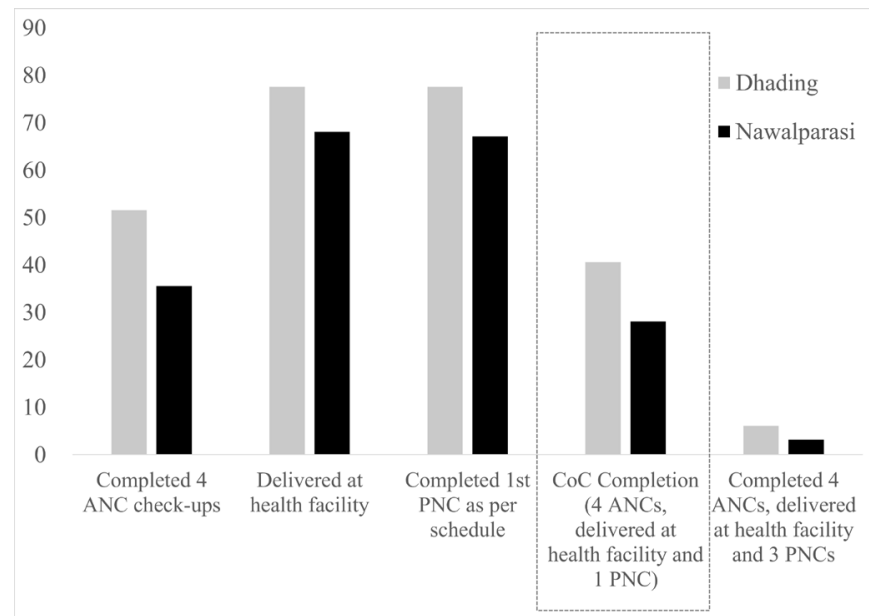

Figure 1 CoC completion rate by district $(\%)(n=1,803)$. ANC, antenatal care; CoC, continuum of care; PNC, postnatal care. 
to choose the place of delivery and decision-makers concerning delivery. The associated factors for CoC completion rate varied by the district as shown in table 2 .

In Dhading, travel time to a birthing centre and wealth quintiles were associated with the CoC completion rate. The mothers who required travelling time of $15 \mathrm{~min}$ to $60 \mathrm{~min}$ to reach the birthing centres had poorer CoC completion rate, as compared with the mothers who had to walk for less than $15 \mathrm{~min}$ (aOR: $0.24,95 \%$ CI: 0.08 to 0.76). CoC completion rate also was poorer among the mothers who travelled for more than $60 \mathrm{~min}$ walk to reach to the birthing centres than the mothers who walk for less than $15 \mathrm{~min}$ (aOR: $0.51,95 \%$ CI: 0.30 to 0.86 ). Mothers in Dhading from the lower (aOR: 8.68, 95\% CI: 3.27 to 23.05), middle (aOR: 3.50 , 95\% CI: 1.33 to 9.24 ), higher (aOR: 4.49, 95\% CI: 1.96 to 10.30 ) and highest (aOR: 2.40, $95 \%$ CI: 1.15 to 5.02 ) wealth quintiles were found with a higher CoC completion rate, as compared with the lowest.

On the other hand, in Nawalparasi, parity and decision making for ANC, planning with husband and decision making for delivery were associated with the CoC completion rate. In Dhading, however, such associations did not show a notable impact on the $\mathrm{CoC}$ completion rate. The mothers having only one child had a better CoC completion rate than those having two children (aOR: 0.33, $95 \%$ CI: 0.13 to 0.83$)$. Mothers who independently opted for ANC were more likely to have a better CoC completion rate than those who relied on the decision of family members (aOR: $0.29,95 \%$ CI: 0.15 to 0.58 ). Aside from that, the mothers who planned the place of delivery with their husband had a better CoC completion rate than the ones planning alone (aOR: $0.38,95 \%$ CI: 0.15 to 0.96 ). In Nawalparasi, it was observed that if the decision-makers for delivery were other family members, particularly the mothers-in-law, fathers-in-law, or husbands, the mothers were more likely to have higher $\mathrm{CoC}$ completion rate (aOR: $3.03,95 \%$ CI: 1.52 to 6.06 ).

\section{DISCUSSION}

This study has two major findings. First, the CoC completion rate was different between two districts: $41 \%$ in Dhading and 28\% in Nawalparasi. Second, different associated factors were detected for the CoC completion rate by districts. They were travel time to the health facility, wealth quintiles, parity, decision-makers for choosing the place of ANC, planning with husband to choose the place of delivery and decision-makers for delivery. Among them, travelling time to health facility and wealth quintile were associated with the CoC completion rate only in Dhading and the other factors were associated with it only in Nawalparasi.

In this study, the CoC completion rates in Dhading and Nawalparasi were $41 \%$ and $28 \%$, respectively. This difference was seen in all the CoC measurement items. First, mothers receiving the four scheduled ANC check-ups that comply with the GoN recommendation in Dhading and Nawalparasi were recorded as $52 \%$ and $36 \%$, respectively. This prevalence was lower than that of the NDHS in 2016; $68 \%$ in hills and 52\% in Terai regions of Nepal. ${ }^{14}$ The difference can be explained by the place of birth in two regions. In this study, mothers delivering at the health institutions made up $78 \%$ and $68 \%$ in Dhading and Nawalparasi, respectively. According to NDHS 2016, this was $59 \%$ in the hill and $50 \%$ in the Terai regions. ${ }^{14}$

Receiving the first PNC within the first 24 hours of delivery was $78 \%$ in Dhading and $67 \%$ in Nawalparasi. The trends of institutional delivery and PNC 1 visit within 24 hours of birth were similar to that observed in NDHS 2016. The GoN recommends mothers and newborns to receive PNC three times within 7 days of delivery, however, only $6 \%$ of mothers in Dhading and $3 \%$ in Nawalparasi were found completing PNC 3. It was quite low despite this intervention being a high priority programme in Nepal. ${ }^{29}$ It was much lower but similar to that reported in other studies. ${ }^{345}$ The prevalence reported in Cambodia was $5 \%$, although the definition used there had been slightly different, ${ }^{34}$ while in Ghana, it was only $8 \% .{ }^{26} 36$

In this study, the mothers in Nawalparasi were more dependent on their husbands, mothers-in-law, and fathers-in-law in choosing the place of ANC or delivery than in Dhading. About $82 \%$ of the mothers in Dhading decided on ANC for themselves whereas only $53 \%$ did so in Nawalparasi. About $75 \%$ of the mothers in Dhading and $27 \%$ of them in Nawalparasi decided the place of delivery independently. In Nawalparasi, mothers were more likely to complete CoC if they decided the place of ANC themselves or planned the selection of the place of delivery with their husband or mother-in-law. Such associations were not significant with the CoC completion rate in Dhading. Hence, this study affirmed that the family members' role (ie, mainly mothers-in-law) was prime in deciding the place of delivery in Nawalparasi. The mothers in Nawalparasi were less empowered, and therefore, less involved in making decisions. Other studies also explained that decision-making by the mother herself in choosing a place of delivery is generally uncommon in rural Nepal. 28 35 37-39

This study has three limitations. First, it covers only the perspective of the mothers, and not that of the health facility staff. Second, the participants represent only mothers from the rural areas of Nepal and the findings can be only generalised for rural women. Finally, as mentioned in the methods, the mountain region was not targeted in this study. This is because mothers live apart in there and obtaining sufficient numbers of data for statistical analysis is difficult.

\section{CONCLUSION}

The CoC completion rate in $\mathrm{MNH}$ was low and different in two ecological regions: Dhading in hill region and Nawalparasi in Terai region. Major factors for the low rate were parity, travel time to a birthing centre, wealth quintiles, spousal communication, decision-makers for 
Open access

Table 2 Multiple variable analysis of CoC (fourth ANC visit, institutional delivery and first PNC visit)

\begin{tabular}{|c|c|c|}
\hline & Dhading ( $n=903)$ & Nawalparasi $(n=900)$ \\
\hline Variables & aOR $(95 \% \mathrm{Cl})$ & aOR $(95 \% \mathrm{Cl})$ \\
\hline \multicolumn{3}{|l|}{ Age group } \\
\hline Below 20 years & 1.00 & 1.00 \\
\hline 20-29 years & 0.62 (0.20 to 1.92$)$ & 4.38 (0.71 to 26.86$)$ \\
\hline Above 30 years & 1.15 (0.50 to 2.64$)$ & 3.82 (0.97 to 15.05$)$ \\
\hline \multicolumn{3}{|l|}{ Education } \\
\hline None & 1.00 & 1.00 \\
\hline Primary/lower secondary & 0.84 (0.33 to 2.11$)$ & $1.53(0.51$ to 4.57$)$ \\
\hline Secondary and above & 1.19 (0.58 to 2.46$)$ & $1.54(0.73$ to 3.25$)$ \\
\hline \multicolumn{3}{|l|}{ Ethnicity } \\
\hline Bramhin/Chhetri/Terai other caste & 1.00 & 1.00 \\
\hline Dalit & 0.67 (0.33 to 1.35$)$ & 2.29 (0.14 to 36.83$)$ \\
\hline Janjati/other caste & 0.60 (0.28 to 1.32$)$ & 1.75 (0.13 to 24.66$)$ \\
\hline Muslim & & 1.75 (0.09 to 34.30$)$ \\
\hline \multicolumn{3}{|l|}{ Religion } \\
\hline Hindu & 1.00 & 1.00 \\
\hline Others & 0.72 (0.39 to 1.34$)$ & 0.49 (0.04 to 5.81$)$ \\
\hline \multicolumn{3}{|l|}{ Travel time to birthing centre } \\
\hline Less than $15 \mathrm{~min}$ & 1.00 & 1.00 \\
\hline $15-60 \mathrm{~min}$ & $0.24(0.08 \text { to } 0.76)^{*}$ & $0.62(0.11$ to 3.46$)$ \\
\hline More than $60 \mathrm{~min}$ & $0.51(0.30 \text { to } 0.86)^{\star}$ & $1.53(0.36$ to 6.45$)$ \\
\hline \multicolumn{3}{|l|}{ Wealth quintiles } \\
\hline Lowest & 1.00 & 1.00 \\
\hline Lower & $8.68(3.27 \text { to } 23.05)^{\star \star \star}$ & $1.21(0.25$ to 5.97$)$ \\
\hline Middle & $3.50(1.33 \text { to } 9.24)^{\star}$ & $1.03(0.22$ to 4.87$)$ \\
\hline Higher & $4.49(1.96 \text { to } 10.30)^{\star \star *}$ & $0.82(0.18$ to 3.85$)$ \\
\hline Highest & $2.40(1.15 \text { to } 5.02)^{\star}$ & $0.73(0.15$ to 3.60$)$ \\
\hline \multicolumn{3}{|l|}{ Parity } \\
\hline One & 1.00 & 1.00 \\
\hline Two & 0.74 (0.37 to 1.49$)$ & $0.33(0.13 \text { to } 0.83)^{*}$ \\
\hline Three or more & 0.51 (0.25 to 1.02$)$ & 1.32 (0.60 to 2.89$)$ \\
\hline \multicolumn{3}{|c|}{ Participated in health mothers' group meeting during pregnancy } \\
\hline Yes & 1.00 & 1.00 \\
\hline No & $0.80(0.41$ to 1.54$)$ & 1.29 (0.65 to 2.56$)$ \\
\hline \multicolumn{3}{|l|}{ Knowledge on 4 ANC check-ups } \\
\hline Yes & 1.00 & 1.00 \\
\hline No & 0.97 (0.47 to 2.02$)$ & 0.96 (0.38 to 2.42$)$ \\
\hline \multicolumn{3}{|l|}{ Decision makers for ANC } \\
\hline Self & 1.00 & 1.00 \\
\hline Others (MIL, husband, FIL) & 1.00 (0.48 to 2.05$)$ & $0.29(0.15 \text { to } 0.58)^{* \star *}$ \\
\hline \multicolumn{3}{|c|}{ Planning with husband for choosing the place of delivery } \\
\hline Yes & 1.00 & 1.00 \\
\hline No & 2.36 (0.95 to 5.81$)$ & $0.38(0.15 \text { to } 0.96)^{*}$ \\
\hline \multicolumn{3}{|l|}{ Decision makers for delivery } \\
\hline Self & 1.00 & 1.00 \\
\hline
\end{tabular}

Continued 
Table 2 Continued

\begin{tabular}{|c|c|c|}
\hline & Dhading (n=903) & Nawalparasi $(n=900)$ \\
\hline Variables & aOR $(95 \% \mathrm{Cl})$ & aOR $(95 \% \mathrm{Cl})$ \\
\hline Others (MIL, husband, FIL) & $0.71(0.38$ to 1.34$)$ & $3.03(1.52 \text { to } 6.06)^{\star *}$ \\
\hline Yes & 1.00 & 1.00 \\
\hline No & $1.10(0.61$ to 2.01$)$ & $0.58(0.30$ to 1.11$)$ \\
\hline Yes & 1.00 & 1.00 \\
\hline No & $0.56(0.21$ to 1.50$)$ & $0.51(0.21$ to 1.21$)$ \\
\hline \multicolumn{3}{|c|}{ Experienced any complications in PNC } \\
\hline Yes & 1.00 & 1.00 \\
\hline
\end{tabular}

${ }^{*} \mathrm{P}<0.05,{ }^{* *} \mathrm{p}<0.01,{ }^{* \star *} \mathrm{p}<0.001$

ANC, antenatal care; aOR, adjusted OR; CoC, continuum of care; FIL, father-in-law; MIL, mother-in-law; PNC, postnatal care.

ANC and delivery. Travel time to a birthing centre and wealth quintile were key factors for poor CoC in Dhading. However, family members' decision in seeking care for ANC and delivery was strongly associated with the CoC completion rate in Newalparasi. Differences in these factors may be reflected by geographical and socioeconomic conditions and the characteristics of household decision making in these regions. These findings will be useful to make tailor-made interventions to improve CoC in different regions.

This study also presented an alarming situation about PNC visits. As the second and third PNC visits were extremely low, we were obliged to use only PNC 1 to define $\mathrm{CoC}$ in this study. Mothers and families face barriers in seeking the second and third PNC as defined by government policy. Government policies might be revised based on the realities identified in this study, in particular, the timing of the second and third PNC check-ups. The findings of this study will be disseminated at local for promoting evidence-based planning to $\mathrm{MNH}$. Home-based care by health workers is theoretically the way to go, but the lack of resources remains a challenge hindering any substantial progress. More studies need to be undertaken to improve the CoC completion rates in resource-limited settings.

Acknowledgements We would like to thank Green Tara Nepal for providing logistical support. Our special thanks go to Professor Edwin van Teijlingen, Salita Gurung, Kamal Gautam, and Kopila Shrestha for their significant contribution. We are also grateful to all the mothers in the rural communities and the research assistants for their kind support in this study.

Contributors RCS and MJ conceived and designed the experiments, while AKP, AS and RCS collectively analysed the data. RCS wrote the paper along with MJ and $A S$, and the finalisation and review of the entire manuscript were done by all the authors: RCS, AS, AKP, SI and MJ.

Funding The authors have not declared a specific grant for this research from any funding agency in the public, commercial or not-for-profit sectors.

Competing interests None declared.
Patient and public involvement Patients and/or the public were involved in the design, or conduct, or reporting, or dissemination plans of this research. Refer to the Methods section for further details.

Patient consent for publication Not required.

Ethics approval Ethical approval for this study was obtained from the Research Ethics Committee of the Graduate School of Medicine, the University of Tokyo (Reference number 11204 dated 26 May 2016). It was also obtained from the Nepal Health Research Council (Reference number 2125, dated 9 June 2016).

Provenance and peer review Not commissioned; externally peer reviewed.

Data availability statement All data relevant to the study are included in the article or uploaded as online supplemental information. Data are shared as supporting information in this manuscript.

Open access This is an open access article distributed in accordance with the Creative Commons Attribution Non Commercial (CC BY-NC 4.0) license, which permits others to distribute, remix, adapt, build upon this work non-commercially, and license their derivative works on different terms, provided the original work is properly cited, appropriate credit is given, any changes made indicated, and the use is non-commercial. See: http://creativecommons.org/licenses/by-nc/4.0/.

\section{ORCID iDs}

Akira Shibanuma http://orcid.org/0000-0003-2058-1722

Subaru Ikeda http://orcid.org/0000-0002-0408-8658

Masamine Jimba http://orcid.org/0000-0001-5659-3237

\section{REFERENCES}

1 Hardee K, Gay J, Blanc AK. Maternal morbidity: neglected dimension of safe motherhood in the developing world. Glob Public Health 2012;7:603-17.

2 Sines E, Tinker A, Ruben J. The maternal-newborn- child health continuum of care: a collective effort to save life. Population Reference Bureau Save the Children 2006.

3 World Health Organisation. WHO recommended interventions for improving maternal and newborn health. Geneva, Switzerland, 2007.

4 Lassi ZS, Bhutta ZA. Community-Based intervention packages for reducing maternal and neonatal morbidity and mortality and improving neonatal outcomes. Cochrane Database Syst Rev 2015:CD007754.

5 Pathak L, Malla D, Pradhan D, et al. Maternal mortality and morbidity in Nepal. Kathmandu, Nepal: Family Health Division, MOHP, 1998.

6 Suwal JV. Maternal mortality in Nepal: unraveling the complexity. Canadian Studies in Population 2008;35:1-26.

7 The Partnership for Maternal Neonatal and Child Health. Our Core Areas of Work: PMNCH knowledge summary \#02 enable the continuum of care. Geneva, Switzerland, 2010. 
8 Acharya DR, Bell JS, Simkhada P, et al. Women's autonomy in household decision-making: a demographic study in Nepal. Reprod Health 2010;7:1-12.

9 Simkhada B, van Teijlingen ER, Porter M, et al. Major problems and key issues in maternal health in Nepal. Kathmandu Univ Med J 2006;4:258-63.

10 Adhikari R. Effect of Women's autonomy on maternal health service utilization in Nepal: a cross sectional study. BMC Women's Health 2016;16.

11 Chalise B, Chalise M, Bista B, et al. Correlates of continuum of maternal health services among Nepalese women: evidence from Nepal multiple indicator cluster survey. PLoS One 2019;14:1-11.

12 Kerber KJ, de Graft-Johnson JE, Bhutta ZA, et al. Continuum of care for maternal, newborn, and child health: from slogan to service delivery. Lancet 2007;370:1358-69.

13 Ensor T, Bhatt $\mathrm{H}$, Tiwari S. Incentivizing universal safe delivery in Nepal: 10 years of experience. Health Policy Plan 2017;32:1117-92.

14 Ministry of Health and Population, New ERA, ICF. Nepal demographic and health survey, 2016. Kathmandu, Nepal, 2017.

15 Family Health Division. Ama Suraksha program, revised strategy. Kathmandu, Nepal: Family Health Division, 2011.

16 Mahato PK, van Teijlingen E, Simkhada P, et al. Factors related to choice of place of birth in a district in Nepal. Sex Reprod Healthc 2017;13:91-6.

17 Dhital R, Silwal RC, Simkhada P, et al. Assessing knowledge and behavioural changes on maternal and newborn health among mothers following post-earthquake health promotion in Nepal. PLoS One 2019;14:1-15

18 Pradhan S, van Teijlingen E, Simkhada PP, et al. Factors affecting the uptake of institutional delivery, antenatal and postnatal care in Nawalparasi district, Nepal. Kathmandu Univ Med J 2019;17:206-11.

19 Central Bureau of Statistics, Planning Commission Secretariat, Government of Nepal. National population and housing census 2011 2012.

20 Ministry of Health and Population. Nepal demographic health survey 2006. Kathmandu, Nepal, 2007.

21 Ministry of Health and Population. Second long-term health plan, 1997-2017. Kathmandu, Nepal: Ministry of Health and Population, 1997.

22 District Development Committee Dhading. Post-Disaster need assessment report. Dhading, Nepal: District Development Committee, 2015.

23 Central Bureau of Statistics National Planning Commission Secreteriat,, The Government of Nepal. Population monograph of Nepal: volume II (social demography. Kathmandu, Nepal, 2014.

24 Central Bureau of Statistics. Statistical pocket book of Nepal. Kathmandu, Nepal: Government of Nepal, 2016.
25 Pantha R, Sharma BR. Chapter two: population size, grwoth and distribution. population census. Kathmandu, Nepal: Central Bureau of Statistics, 2002.

26 Yeji F, Shibanuma A, Oduro A, et al. Continuum of care in a maternal, newborn and child health program in Ghana: low completion rate and multiple obstacle factors. PLoS One 2015;10:e0142849.

27 Khanal V, Adhikari M, Karkee R, et al. Factors associated with the utilization of postnatal care services among the mothers of Nepal: analysis of Nepal demographic health survey 2001. BMC Womens Health 2014;14.

28 Simkhada B, Porter MA, van Teijlingen ER, Maureen A. The role of mothers-in-law in antenatal care decision-making in Nepal: a qualitative study. BMC Pregnancy Childbirth 2010;10:34.

29 Family Health Division. National safe motherhood and neonatal health long term plan: 2006-2017. Kathmandu, Nepal: Family Health Division, 2006.

30 Family Welfare Division. Nepal safe motherhood and newborn health road map 2030. Kathmandu, Nepal, 2020.

31 Chow S-C, Shao J, Wang H. Sample size calculation in clinical research. CRC Biostatitics series. second ed.. London, UK: Champion and Hall, 2003.

32 Ministry of Health and Population, New Era, Macro International Inc. Nepal demographic health survey, 2011. Kathmandu, Nepal: Ministry of Health and Population, 2012.

33 Ministry of Health and Population Nepal, Prevention of Maternal Neonatal Child Health, World Health Organisation, World Bank, AHPSR. Success factors for women and children's health Nepal. Geneva, Switzerland, 2014.

34 Kikuchi K, Yasuoka J, Nanishi K, et al. Postnatal care could be the key to improving the continuum of care in maternal and child health in Ratanakiri, Cambodia. PLoS One 2018;13:1-13.

35 Iqbal S, Maqsood S, Zakar R, et al. Continuum of care in maternal, newborn and child health in Pakistan: analysis of trends and determinants from 2006 to 2012. BMC Health Serv Res 2017;17:189.

36 Shibanuma A, Yeji F, Okawa S, et al. The coverage of continuum of care in maternal, newborn and child health: a cross-sectional study of woman-child pairs in Ghana. BMJ Glob Health 2018;3:e000786.

$37 \mathrm{Kc} \mathrm{S}$, Neupane S. Women's autonomy and skilled attendance during pregnancy and delivery in Nepal. Matern Child Health $J$ 2016;20:1222-9.

38 Culhane-Pera KA, Sriphetcharawut S, Thawsirichuchai R. 'We all decided': The variations of Hmong Family-Based DecisionMaking about Maternity Care in Thailand. J Pregnancy Child Health 2015;02:1-6.

39 Osamor PE, Grady C. Women's autonomy in health care decisionmaking in developing countries: a synthesis of the literature. Int J Womens Health 2016;8:191-202. 